J. Chem. Soc. Nigeria, Vol. 45, No.6, pp 1066 - 1072 [2020]

\title{
HEAVY METAL CONCENTRATION AND PROXIMATE ANALYSIS OF SOME SELECTED POULTRY LAYERS FEED PRODUCED IN ADO ODO OTA LOCAL GOVERNMENT
}

\author{
S. O Aminu $^{1 *}$ and F.M. Oladipo ${ }^{1}$ \\ ${ }^{1}$ Science Laboratory Technology Department, Ogun State Institute of Technology Igbesa, Ogun \\ State. \\ *Correspondence: aminufernandez@yahoo.com, oladipofolasade3@gmail.com \\ Received 08 September 2020; accepted 01 October 2020, published online 20 October 2020
}

\begin{abstract}
Foods including feed of animals are known to be contaminated with heavy metals and other microbial sources originating from their raw materials, water or processes involved in their preparation or formulation. This study focused on assessing the heavy metal concentration, ash content, moisture content and $\mathrm{pH}$ of three different feeds sold around Ado Odo Ota Local Government Area of Ogun State, Nigeria. It was observed that the ash contents of the products varies from $13.19 \%$ to $35.24 \%$; moisture content ranges from $4.12 \%$ to $8.16 \%$ while the three feed are of neutral $\mathrm{pH}$ value. The heavy metals concentration varies across each sample (Iron $2.644 \mathrm{mg} / \mathrm{kg}$ to $6.713 \mathrm{mg} / \mathrm{kg}$; Lead $0.15 \mathrm{mg} / \mathrm{kg}$ to $6.7 \mathrm{mg} / \mathrm{kg}$; copper $0.00 \mathrm{mg} / \mathrm{kg}$; Zinc $0.065 \mathrm{mg} / \mathrm{kg}$ to $0.572 \mathrm{mg} / \mathrm{kg}$; Chromium $0.003 \mathrm{mg} / \mathrm{kg}$ to $0.127 \mathrm{mg} / \mathrm{kg}$ and Manganese $1.946 \mathrm{mg} / \mathrm{kg}$ to $3.113 \mathrm{mg} / \mathrm{kg}$ ). All parameters obtained were below the Federal Agricultural Organization and World Health Organization except that of Lead obtained in Mubat Feed sample coded as $\mathrm{C}$ which is $6.7 \mathrm{mg} / \mathrm{kg}$ which could have deleterious effect on the health status of layers fed with such feed as well that of man upon consumption of such poultry eggs or meat.
\end{abstract}

\section{INTRODUCTION}

Poultry feed is food for farm poultry, including chickens, ducks, geese and other domestic birds. According to (14), domesticated bird meat is the second most widely eaten meat in the world, responsible for about $30 \%$ of meat consumed after beef $(38 \%)$. These birds are kept by humans for the purpose of egg collection, meat and feathers. Foods including feed of animals are known to be contaminated with heavy metals and other microbial sources originating from their raw materials, water or processes involved in their preparation or formulation.

Modern feeds for poultry consists largely of grain, protein supplements such as soybean oil meal, mineral supplements, and vitamin supplements. The quantity of feed and the nutritional requirements of the feed depend on the weight and age of the poultry, their rate of growth, their rate of egg production, the weather (cold or wet weather causes higher energy expenditure), and the amount of nutrition the poultry obtain from foraging. This results in a wide variety of feed formulations. Healthy poultry require a sufficient amount of protein and carbohydrates, along with the necessary vitamins, dietary minerals, and an adequate supply of water.

Lactose-fermentation of feed can aid in supplying vitamins and minerals to poultry. Egg laying hens require 4 grams per day of calcium of which 2 grams are used in the egg. Oyster shells are often used as a source of dietary calcium. Certain diets also require the use of grit, tiny rocks such as pieces of granite, in the feed. Grit aids in digestion by grinding food as it passes through the gizzard. 
It has been reported that most commercial feeds failed to meet up with the national requirement of birds and in many way the raw materials for the production of the feeds are somehow associated with heavy metals pollution (8).

Heavy Metal is used to describe more than a dozen elements that are metals or metalloids e.g. chromium, arsenic, cadmium, lead, mercury, manganese etc. Living organisms require varying amount of "heavy metals" be it iron, cobalt, copper, manganese, molybdenum and zinc. Excessive levels can be damaging to the organisms. Therefore heavy metals can be described as any metallic element that has a relatively high density and is toxic or poisonous at low concentrations (3). Some mineral elements such as copper, iron, manganese and zinc are essential dietary nutrients for poultry and livestock; however, all mineral elements, whether considered to be essential or potentially toxic, can possess adverse effect on humans and animals health if included in the diet at excessively high concentrations (2). Zinc, an essential element needed by the body in small amounts but lack or insufficient quantity could cause loss of appetite, decreased immune function, slow wound healing, and skin sores. Human diets with too little manganese can lead to slowed blood clotting, skin problems, lowered cholesterol levels, and other alterations in metabolism (3).

Manganese consumption at very low concentration can interfere with normal growth, bone formation, and reproduction. Copper is an essential element for all known living organisms including humans and other animals at low levels of intake. However, exposure to higher doses can be harmful. Long-term exposure to copper dust can irritate nose, mouth, and eyes, and cause headaches, dizziness, nausea, and diarrhea Lead exposure has been associated with elevated blood pressure and hypertension (9). Cadmium toxicity has been linked to prostate cancer and cancer in liver, kidney and stomach. The most serious harmful health effects from exposure to nickel are reduced lung function, and cancer of the lung, respiratory tract irritation and asthma .Excess cobalt in the body causes harmful effects in the body such as trouble breathing, serious effects on the lungs, asthma and skin rashes (6). Various organisms within a given ecosystem are contaminated along their cycles of food chain with heavy metals. There are several reasons for concern about the possibility of excessive mineral intakes by poultry. Natural water supplies can contain high concentrations of magnesium and iron. In addition, numerous toxic elements, especially heavy metals, can be added to ground water from hazardous waste sites, industrial pollution, and municipal waste systems. Another potential source of contamination is that resulting from human error during transport and mixing of ingredients and final delivery of a finished feed to the poultry house. Heavy metals have been associated with automobile related pollution. They are often used as minor additives to gasoline and various auto-lubrication, and are released during combustion and spillage Cobalt occurs naturally in soil, rock, air, water, plants, and animals. Soils contaminated by airport traffic, highway traffic, or other industrial pollution may contain high concentrations of cobalt. Small amounts of cobalt may also be released into the atmosphere from coal-fired power plants and incinerators, vehicular exhaust (10). Humans are also in turn exposed to these heavy metals by consuming the contaminated plants and animals.

Most zinc enters the environment as the result of mining, purifying of zinc, lead, and cadmium ores, steel production, coal burning, and burning of wastes. These activities can increase zinc levels in the atmosphere (1). Copper enters the environment through waste dumps, domestic waste water, combustion of 
fossil fuels and wastes, wood production, phosphate fertilizer production, and natural sources. Therefore, copper is widespread in the environment, infact, studies carried out on heavy metals analysis in blood sample of the urban population in Nigeria show high levels of the heavy metals attributed to environmental pollution from fossil fuels combustion and also indiscriminate waste disposal. Chickens are one of the main sources of protein for the south west population especially in Ado odo ota local government area of Ogun state where there are several poultry farms and abundant markets. The chickens are nourished by the feeds they consume which as a result of heavy metal pollution in the country might be poisonous and therefore detrimental to the health of the human population that consume the chickens. There is insufficient data as to the nutritive content of feeds consumed by chickens in the country and possible contamination of the feeds by the nutritive elements. So far no work has been carried out to cover the south west; therefore this study was carried out to determine the concentration of zinc, iron, manganese, copper, lead, cadmium, nickel and cobalt in chicken feeds obtained within Ado odo ota local government area of Ogun State.

The quality yield of poultry birds depends on the specification of feed, water, breeds, environmental conditions, medication, feeding trough, water trough and the handling pattern of the farmer (11). Poultry feeds is the most essential among these factors for these animals, contributing to about $60-80 \%$ of the economic cost input in the commercial poultry industries $(5 ; 7)$. Due to this, the feeds sold within Ado odo ota local government were analyzed for heavy metal contamination $(\mathrm{Fe} \mathrm{Pb}, \mathrm{Zn}, \mathrm{Cu}, \mathrm{Cr}$, and $\mathrm{Mg}$ ), ash content, moisture and $\mathrm{pH}$ to ascertain the quality of the feeds.

\section{METHODOLOGY Collection of Materials}

Three different branded layer chicken feed were purchased within Igbesa-Lusada metropolis in Agbara/Igbesa Local Council Development Area of Ado Odo Ota Local Government Area of Ogun state of Nigeria. He feeds were labeled as sample A, B and C.

\section{Determination of moisture content}

$10 \mathrm{~g}$ of each chicken feed sample was weighed in to a crucible and put in the oven for 1-2hrs at $100-105^{\circ} \mathrm{C}$, after that it was placed inside the desiccator to cool.

Calculation

$\mathrm{W} 1=$ weight of sample

$\mathrm{W} 2=$ weight of dry sample

$$
\% \mathrm{MC}=\frac{\mathrm{W} 1-\mathrm{W} 2}{\mathrm{~W} 1} \times 100
$$

\section{Determination of Ash content}

$10 \mathrm{~g}$ of each chicken feed sample was weighed into a crucible and put in the muffle furnace for $4 \mathrm{hrs}$ at $480^{\circ} \mathrm{C}$, after that it was placed inside the desiccator to cool.

Calculation

$\mathrm{W} 1=$ weight of sample

$\mathrm{W} 2=$ weight of dry sample

$$
\% \text { Ash content }=\frac{\mathrm{W} 1-\mathrm{W} 2}{\mathrm{~W} 1} \times 100
$$

\section{SAMPLE PREPARATION FOR DETERMINATION OF HEAVY METALS}

$2 \mathrm{~g}$ of each brand was weighed into different crucibles. $1 \mathrm{ml}$ of conc. nitric acid was added and then pre-ashed by placing the crucible on a heater until the contents charred. The pre-ashed samples were then transferred into a muffle furnace with a temperature of $480^{\circ} \mathrm{C}$ for $4 \mathrm{hrs}$ after which they were allowed to cool.

The cooled samples were dissolved using $5 \mathrm{ml}$ of $30 \% \mathrm{HCl}$ and then filtered using Whatman filter papers. The filtrates were individually poured into $50 \mathrm{ml}$ standard flask and made up to mark with deionized water. These were then transferred into prewashed sample bottles for analysis of the trace metals (Okeye et al., 2010). 


\begin{tabular}{|c|c|c|c|c|c|c|}
\hline Feed Sample & $\begin{array}{l}\text { Iron } \\
(\mathrm{Mg} / \mathrm{Kg})\end{array}$ & $\begin{array}{l}\text { Lead } \\
(\mathrm{Mg} / \mathrm{Kg})\end{array}$ & $\begin{array}{l}\text { Copper } \\
(\mathrm{Mg} / \mathrm{Kg})\end{array}$ & $\begin{array}{l}\text { Zinc } \\
(\mathrm{Mg} / \mathrm{Kg})\end{array}$ & $\begin{array}{l}\text { Chromium } \\
(\mathrm{Mg} / \mathrm{Kg})\end{array}$ & $\begin{array}{l}\text { Manganese } \\
(\mathrm{Mg} / \mathrm{Kg})\end{array}$ \\
\hline $\bar{A}$ & 2.644 & 0.150 & 0.000 & 0.572 & 0.003 & 2.816 \\
\hline B & 6.713 & 1.510 & 0.000 & 0.562 & 0.127 & 1.946 \\
\hline $\mathbf{C}$ & 5.513 & 6.700 & 0.000 & 0.065 & 0.042 & 3.113 \\
\hline FAO/WHO/ & $45-80$ & 5 & $9-10$ & $30-40$ & 0.3 & $20-60$ \\
\hline
\end{tabular}

The sample solutions were then analyzed for zinc, iron, manganese, copper, lead, and chromium at required wavelength using atomic absorption spectrophotometer (AGILENT 55AA) at Jawura Environmental Services Limited.

\section{RESULT AND DISCUSSION}

Table 1: Ash, Moisture and pH of Three Different Chicken Feed

\begin{tabular}{|c|c|c|c|}
\hline Parameter & $\mathbf{A}$ & B & $\mathbf{C}$ \\
\hline $\begin{array}{l}\text { Ash content } \\
(\%)\end{array}$ & 35.24 & 13.19 & 20.13 \\
\hline $\begin{array}{l}\text { Moisture } \\
\text { content (\%) }\end{array}$ & 6.27 & 8.16 & 4.12 \\
\hline $\mathrm{PH}$ & 7.1 & 7.3 & 7.4 \\
\hline
\end{tabular}

\section{- Ash content (\%) $\square$ Moisture content (\%) $\square \mathrm{PH}$}

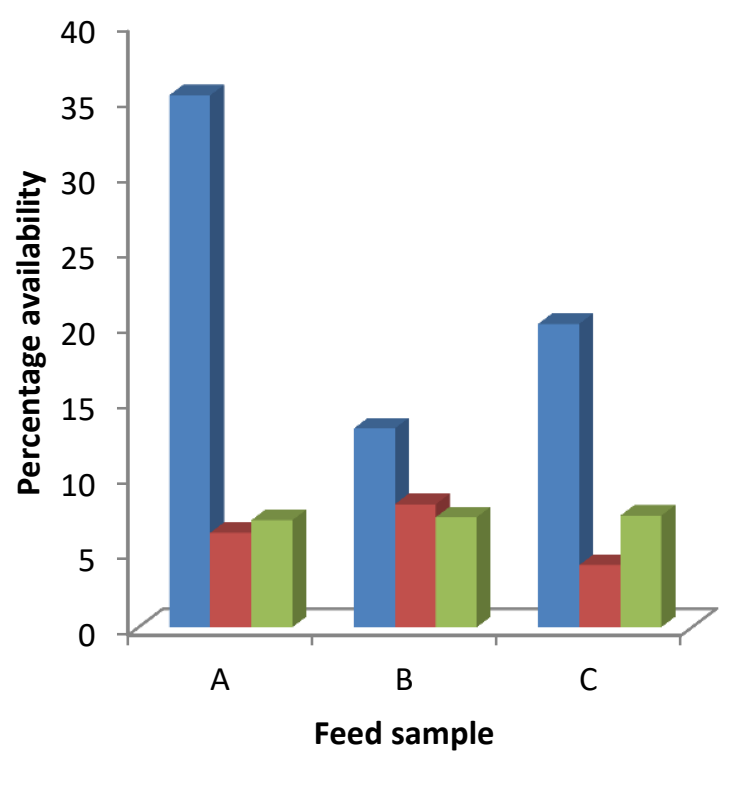

Figure 1: Percentage Availability of Ash content, Moisture Content and $\mathrm{pH}$ of the Feed $\mathrm{A}, \mathrm{B}$ and $\mathrm{C}$ 
J. Chem. Soc. Nigeria, Vol. 45, No.6, pp 1066 - 1072 [2020]

Table 2: Heavy Metal Analysis of Three (3) Different Feeds

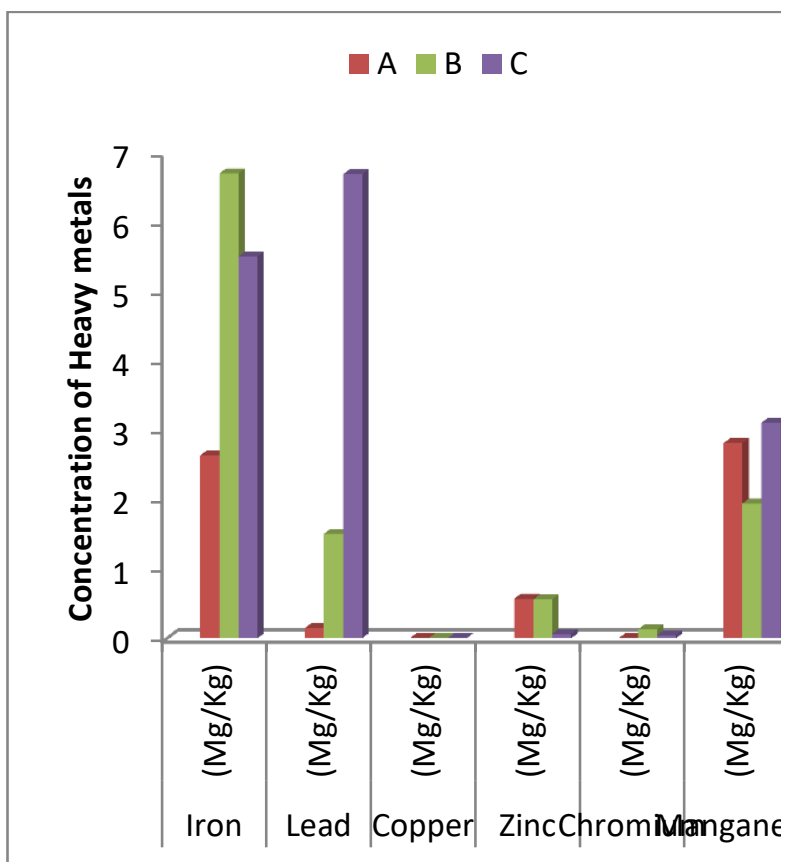

Figure 2: Heavy Metal Concentration of Feed $\mathrm{A}, \mathrm{B}$ and $\mathrm{C}$ 


\section{DISCUSSION \\ Moisture Content}

In table 1, moisture content is the presence of liquid, especially water, often in trace amount. The analyzed moisture content varied between $4.12 \%$ in Sample C to $8.16 \%$ in Sample B.

(Sorensen, 2003) reported that moisture content reduced to below $8 \% \mathrm{M}$ increase shelf life during storage. The presence of moisture above specified quantity can lead to increased microbial growth resulting to spoilage of the feed and eventual causal disease to the bird if fed with the same feed

The national Research council (1981) reported that feed stored in an area with high moisture and/or high temperature will cause per oxidation of the lipid and degradation of vitamin.

\section{Ash Content}

Ash content refer to inorganic residue which main constitutes are minerals contained in feed sample. The analyzed ash content of the commercial chicken feed sample was in the range of $13.19 \%$ in top feed to $35.24 \%$ in hybrid feed. The feed sample has high value, the normal ash content of chicken feed range from $7 \%$ to $12 \%$. The percentages of ash presented in the sample represent the mineral matter of the feed.

\section{Heavy Metals}

The concentration of Iron in this study is below the value of $45-80 \mathrm{mg} / \mathrm{kg}$ specified by FAO

The results obtained from table 2 , shows the concentration of copper ranges from (2.644$5.513 \mathrm{mg} / \mathrm{kg}$ ), an essential micro-nutrient was far below the required range in all brands of feed. The Iron content of three chicken feeds which

\section{REFERENCES}

1. F. O., Abulude, Y. S. Akinjaagunla and A. Omoniyi (2006). An investigation into the effect of vehicular exhaust fumes on the levels of some heavy metals in cows' blood. Research Journal of Biological Sciences, 1(1-4): 9-11.

2. F. O Abulude., S. O. Eluyode and A. Jegede (2006b).An investigation into the effect of traffic pollution on the levels of some heavy metals in goats' urine samples .Journal of Animal and Veterinary Advances, 5(2): 132-134. are Samples A, B and C were found to be low in concentration compared to study conducted by (13). The values of Copper range was (0.000) but below the micronutrients quantity specified for layers feed by FAO and WHO (2010) standard as captured in table 2.The Zinc content ranges from $(0.572-0.065 \mathrm{mg} / \mathrm{kg})$ which is lower to values obtained by (13). Manganese is also an essential trace mineral required for many biological processes (4), and all the feeds sampled contained manganese at a concentration higher than the recommended (12) but below the specified value of $20-60 \mathrm{mg} / \mathrm{kg}$. The values obtained range from $(2.816-3.113 \mathrm{mg} / \mathrm{kg})$. This could be as a result of un-harmonized nutritional requirements of chicken which differs from one area to another and errors during processing and mixing of ingredients to the feed. Also, inadequacies of some of these essential metals as shown in this study, when compared with the recommended values of (12), also revealed inadequate supplementation of these metals in the feed. Chromium was detected with value ranging from $0.03-0.127 \mathrm{mg} / \mathrm{kg}$ but below the specified $0.3 \mathrm{mg} / \mathrm{kg}$ (Act No.21 of (12)).

Lead is non-essential elements that are of direct health concern to both poultry and humans (4). These metals are more of contaminants than nutrients, therefore should be main concern in discussing heavy metals in poultry. The concentration of lead obtained from this evaluation was found to be lower which ranges from $(0.150-6.700 \mathrm{mg} / \mathrm{kg})$ but exceeds that of permissible limit of $1 \mathrm{mg} / \mathrm{kg}$ in the United Kingdom while only sample $C$ exceeds the value of $5 \mathrm{mg} / \mathrm{kg}$ stated.

3. M Aschner. (2002). Neurotoxic mechanism of fish-borne methylmetry.Environmental Toxicology and Pharmacology, 12(2): 101-102.

4. Costa (2010).Trace elements; Aluminum, Cadmium, Arsenic and Nickel. In: Environmental Metal Toxicants, Human Exposure and their Health effect, 2Ie. John Wiley and sons, Inc. New York City. Pp 811-850.

5. A Elmasoeur. and N Russ. (2013). Ghana Poultry Report Annual. Global Agricultural information Network 
prepared by USDA Staff in Gain report No. (1304).

6. M. S., Islam, M. A. I., Kazi, M. M., Hossain M. A Ahsan. and A. M Hossain. (2007). Propagation of heavy metals in poultry feed production in Bangladesh. Bangladesh Journal of Scientific and Industrial Research, 42(4): 456-474.

7. R .Kleyn. (1992). Broiler feeding for better returns. Pout. Bullet. 283-286.

8. S. A Mahesar., S. T. H., Sherazi M. I., Abdul Niaz and S. A Bhanger. (2010). Simultaneous assessment of zinc, cadmium, lead and copper in poultry feeds by differential pulse anodic striping voltammetry. Food and Chemical Toxicology doi: 10.1016/j.fct.2010.05.071.

9. S. A Martin. S. T Sherazi., A., Niaz M. I., Bhanger S.. Uddin and A. Rauf (2010). Simultaneous assessment of zinc, cadmium, lead and copper in poultry feeds by differential pulse anodic stripping voltammetry. Food and
Chemical Toxicology, 48(8-9): 23572360.

10. L. R McDowell. (2012). Minerals in Animal and Human Nutrition: Comparative Aspects to Human Nutrition. Second edition, Academic Press Inc., San Diego, USA.Pp 246-263.

11. M. M. Nazri (2003). Development of poultry industry. Economic review, Available online at: Nazri, M .M. Development of poultry industry. Economic Review, March 2003 Issue.

12. NRC (1994).Nutrient Requirements of Poultry.9th revised edition, National Academy of Sciences, Washington, DC.Pp 19-34.

13. C. O. B Okoye., C. N Ibeto. and J. N Ihedioha. (2011). Assessment of heavy metals in chicken feeds sold in south eastern Nigeria. Advances in Applied Science Research, 2(3):63-68.

14. , J. Raloff (2003). Food for thought: Global Food Trends. Science new online. May 31, 2003. 